\title{
COLLABORATION SKILLS OF 8TH GRADE SECONDARY STUDENTS IN SCIENCE LEARNING WITH ENGINEERING DESIGN ACTIVITY
}

\author{
Fitri Nuraeni ${ }^{1 *}$, Anna Permanasari ${ }^{1}$ and Riandi ${ }^{1}$ \\ ${ }^{1}$ Universitas Pendidikan Indonesia, Indonesia
}

\begin{abstract}
Collaboration is now identified as an essential 21 st century skills that make it become an important learning outcome. On the other hand, there is a growing demand to infuse engineering practices into science learning as it relies more on social involvement, such as collaboration, to solve problems. Thus research examining students' collaboration skills which emerge during activities involving engineering design is needed. Through observation method with rubric adapted from social skills of collaborative problem solving, emerging collaboration skills during collaborative engineering design processes are identified. The subject were 18 secondary students in 8 th grade who were engaged in science lesson involving designing, constructing and testing analogical model of blocked artery and medical device to treat it. Varied level of participation, perspective taking and social regulation skills are evident throughout the lesson. Finding suggests that individual collaboration skills are dependent upon skills of collaborating partner
\end{abstract}

Keywords: Collaboration, engineering design, science learning

\section{Introduction}

Collaboration is identified as an essential 21 st century skills because current workforce, living and citizenship are now dominated by complex problems that often require multidisciplinary solutions which should be done collaboratively instead of by individual alone. Accordingly, recent curriculum reforms in Indonesia have acknowledged the importance of collaboration skills to tackle 21 st century challenges. Now, science learning is expected to attribute children with learning skills that include critical thinking, problem solving and creativity as well as able to communicate and collaborate (Kemendikbud, 2017).

On the other hand, there has been a demand to incorporate engineering approach into science learning (Wendell \& Rogers, 2013). The engineering design practices are regarded as promising vehicle to boost science learning and achievement (Yanyan et al., 2016). Moreover, the use of engineering design support the development of twenty first century skills (Guzey et al., 2016) as it provide students with an effective way to tackle open-ended problems (Yanyan et al., 2016). At the same time, engineering design deepens their understanding of crosscutting concepts and ideas from related disciplines (Hernandez et al., 2014). In engineering design-based instructions, regardless the approach of engineering integration which is used, activities done by students always involve collaborative work as a team instead of individuals (Wendell \& Rogers, 2013).

Incorporating engineering design into instructions has attracted increased attention as numerous researchs shown promising findings. However, current studies have not yet investigated in detail on how collaboration skills emerge within engineering design based science environment. Most studies focused on how such instructions improve science content gain (Barrett et al., 2014; Marulcu \& Barnett, 2016; Moreno et al., 2016; Wendell \& Rogers, 2013), problem solving skills (Yanyan et al., 2016) and attitude toward science and engineering (Guzey et al., 2016; Wendell \& Rogers, 2013). In light to that, this study aims to provide insight about how collaboration skills appear within engineering design activity in science lesson as well as identify how well the students perform those skills. 


\section{Research Framework}

Collaboration is considered as an essential learning outcome for the twenty-first century (Lee, Huh \& Reigeluth, 2015 ) as it contributes to one's personal success in the collaborative learning context and workplace (Lai, DiCerbo \& Foltz, 2017). Lai et al. (2017) define collaboration as the process of interaction that requires individuals to work together toward a common goal. It is characterized by interdependence among group members (Riebe et.al, 2016) and coordination between the members to construct and maintain a shared conception of a problem (Rochelle and Teasley, 1995). Similarly, Griffin (2015) describes that collaboration is the activity of working together to reach a common goal where communication, cooperation and responsiveness are used as its building block.

There are two dimensions of collaboration which includes interpersonal skills and self-management skills (Stevens and Campion, 1994). One of the most cited conceptualization of collaboration under interpersonal skills is collaborative problem solving (Lai et. al., 2017) which refers to collaboration within problem solving activity. Here, collaboration serves as the social domain that provides more advantages compared to individual problem solving as it allows effective division of labor, incorporation of information from various perspective, experiences and sources of knowledge and enhance creativity and quality of solutions through stimulation from other's idea (OECD, 2017). In contrast to individual problem solving, the steps to reach collaborative solution in collaborative problem solving is observable through verbal and non-verbal signals (Griffin et al., 2015) shown by each of the individual members of the group.

According to Hesse, et al., (2015), the collaboration skills in collaborative problem solving comprises of three capabilities as follow:

\section{Participation}

There are three indicators of observable behavior that inferred student participation, namely action, interaction and task regulation. Action describes the level of individual participation in general without taking into account whether the action is in coordination with others' effort ranging from whether the student is passive, active, dependent upon prompt and support, or initiate the action independently. Interaction is defined as the capacity to give response to action or do coordination with other group members. The level of interaction started from simply answering an inquiry, to initiating and arranging efforts actively or stimulates other to respond. Task completion skills refer to the driving force of participation which includes sense of responsibility for the outcome of collaborative work.

\section{Perspective Taking}

Perspective-taking refer to the individual ability to see a situation from other's perspective, which includes responsiveness and audience awareness as its sub skill elements. Responsiveness describes as a set of skills to integrate contribution of others in collaborating group into students own thought or action that involve accepting, ignoring or adapting contributions of others. On the other hand, audience awareness described as the ability to tailor contributions to others' needs which require the awareness of how to adapt behavior that is more suitable for other to respond.

\section{Social Regulation}

Social regulation is needed for the sake of diversity of knowledge, experiences and resources which is used in problem solving. The sub skills for social regulation are metamemory, transactive memory, negotiation skills and responsibility initiative. Metamemory refer to the ability to evaluate his or her own knowledge as well as 
strengths and weaknesses. Transactive memory described as individual understanding of knowledge, strengths and weaknesses of others. Negotiation skill involves the act to compromise or reaching a resolution. Responsibility initiative skills refer to the ability to take initiative in different ways such as focus on individual tasks, work on shared problem representation, initiate strategic plan and monitor groups progress.

\section{Engineering Design}

To collaborate, students need to engage in a lesson where the content is debatable and on which varied perspectives exist (Lie et al, 2017). Integrating engineering design into the lesson could be a way to develop collaboration skills. It is because, when compared to many other fields, engineering activities relies more on social involvement, cooperation and collaboration to solve the problems (Housholder and Hailey, 2012). In addition, engineering activities encourage students to contextualize the problem with respect to existing knowledge and experience as well as to communicate what they learned as a result (Rush, 2010). Moreover, engineering activities is student driven, interdisciplinary, collaborative, and technology based (Han et al, 2014).

Engineering itself is defined as the action to improve lives by transforming the world in such a way using the knowledge and observation (Bagiati \& Evangelou, 2016). Specifically, Yanyan et al., (2016) define engineering as the application of science to solve problems. Wendell \& Rogers (2013) defined engineering as the process of designing and prototyping a tangible solution, or the model of a solution, to an authentic problem. It is in line with the statement of other researcher who said that the central part of engineering is the act of designing in which the engineers use when they are trying to create new technology or solve particular problems (Guzey et al., 2016) that employs cognitive reasoning, mental models and operation that has to fulfill constraints (Lewis in Schnittka et al., 2016).

Several studies identified three approaches to incorporate engineering practices into instruction (Marulcu \& Barnett, 2016; Schnittka et al., 2016; Wendell \& Rogers, 2013): (1) design based modeling developed by Penner et al., (2) engineering for children by Roth and (3) Learning by Design by Kolodner et al. Studies on various science concept and design challenge has been addressed using these three approaches where the activities done by students always involve the iterative process of engineering design namely: (1) Identify Problems, (2) Develop possible solution, (3) Design the prototype that fulfill criteria and constraint, (4) Construct the prototype, (5) Test the prototype, and (6) Redesign.

A number of studies have revealed advantages of engineering design activity on particular learning domains. Finding shown that the engineering design-based science is somehow connected with improvement in science content gain (Barrett et al., 2014; Marulcu \& Barnett, 2016; Moreno et al., 2016; Wendell \& Rogers, 2013) and problem solving (Yanyan et al., 2016). In attitudinal domain, it is found that engineering design based science produced positive attitude toward science and engineering (Guzey et al., 2016; Wendell \& Rogers, 2013). However, even though collaboration and teamwork is an essential component in engineering design activity, no studies have yet elaborated in details as how the collaboration skills could be fostered. Thus, there is a need for more studies that document collaboration skills which occurred during the lesson incorporating engineering design activity.

\section{Methods}

To provide insight about how collaboration skills appear within engineering design activity in science lesson the descriptive method was implemented. The observation technique was used to capture students' collaboration skills. Two observers did the observation along meeting 2 until meeting 4. Each observed males and females group separately. Female and male students were assigned in different group following school's regulation. Group assignment is made based on subject teacher's consideration to ensure that each group is heterogenic. 
The observers used observation rubric which is developed from the indicator of collaboration skills in collaborative problem solving by Hesse et. al. (2015). Prior to observation, researcher sits together with the two observers to ensure similar perspective regarding the rubrics. Due to the complexity of the skills, an audio recorder for each group is used to capture students' discourse during the lesson to ensure that there is no missing evident. In addition, interesting findings during the lesson was recorded in observers' notes.

Observed behavior indicated particular elements in the three sub skills was then rated from 1 to 3 points that represent low, medium and high level of the skill. The scoring is used to compare students' average performance in each engineering design process to see at which process particular collaboration skill is best performed. The level of collaboration skills emerge in each engineering design process is elaborated in form of percentage of students performing those skills.

\section{Context}

This study took place in one of private school in Lembang area, Bandung, West Java which combines national curriculum and Cambridge curriculum. The subjects were 18 students in 8th grade secondary level who were engaged in 4 meetings-lessons involving engineering activity. The topic discussed along the lesson is related to disease in circulatory system and means to treat it. Students were given engineering journal to document their work along the lesson.

During lesson 1, students were introduced to several diseases in circulatory system. The teacher then further directed students to discuss about coronary heart disease (CHD). This disease will then be used as the context for the engineering activities students will have in the upcoming meetings. This lesson aimed to help students construct sufficient knowledge before they engage in engineering activities. Teacher used PowerPoint slides to guide whole class discussion about causes and symptoms of CHD as well as general overview about means to treat it, including angioplasty method. Furthermore, teacher shown video about how angioplasty method is done but limited to how the catheter is inserted into human body.

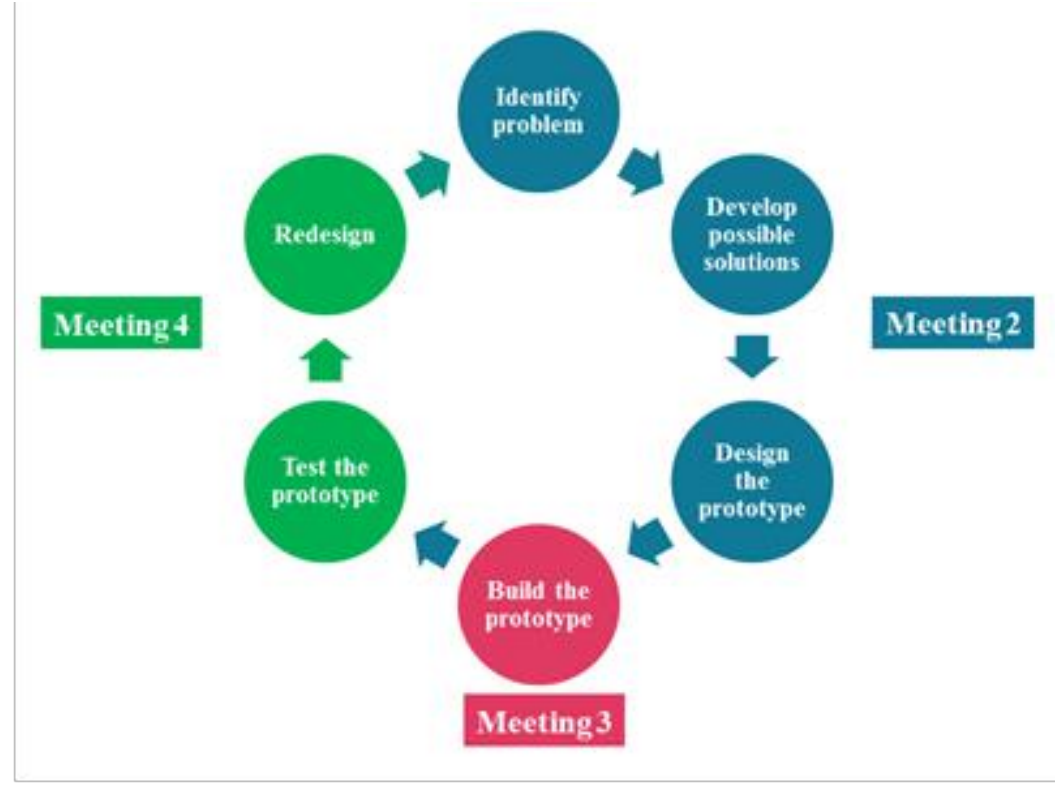

Figure 1 Engineering Design Process in meeting 2, 3 and 4

In lesson 2, the students started to engage in the first three engineering design processes, namely identify problem, develop possible solutions, and design the prototype that fulfill criteria and constraints. In the 
beginning of the lesson, researcher who acted as the teacher assigned the students into group of three or four. In this lesson, students were given an ill-structured problem in form of scenario where students acted as medical engineer. Each group was encouraged to identify the main problem and state it in question form. Each group were then need to think about possible solutions to that problems. After that, teacher explained criteria and constraint that their solution should fulfill. Based on that criteria and constraint each group will then decide the best solution and draw the design of the prototype. In addition, students also have to indicate the materials that they need along with its amount.

In lesson 3, each group was asked to construct the prototype based on the design that they have made. The prototypes made by students are analogical model of blocked artery and catheter to be used in angioplasty method. All materials were provided by the teachers. The prototypes were then tested in lesson 4. Each group took turn to test their prototype in front of the class. To check the effectiveness of their catheter, students measured the time taken for $2 \mathrm{~L}$ of blood, which is made from water and food coloring, to flow through the artery before and after the treatment with catheter. In redesign, students were guided to improve their prototype based on strengths and weaknesses they have found during testing.

\section{Results}

Table 1 Percentage of students performing collaboration skill during engineering design activity in meeting 2.

\begin{tabular}{|c|c|c|c|c|c|c|c|c|c|}
\hline \multirow{3}{*}{ Elements of Collaboration Skills } & \multicolumn{9}{|c|}{ Engineering Design Process } \\
\hline & \multicolumn{3}{|c|}{ Identify problem } & \multicolumn{2}{|c|}{$\begin{array}{l}\text { Develop } \\
\text { solution }\end{array}$} & possible & \multicolumn{3}{|c|}{ Design prototype } \\
\hline & Low & Mid & High & Low & Mid & High & Low & Mid & High \\
\hline P1 - Action & 16.7 & 27.8 & 55.6 & 16.7 & 27.8 & 55.6 & 16.7 & 27.8 & 55.6 \\
\hline $\mathrm{P} 2$ - Interaction & 16.7 & 27.8 & 55.6 & 0 & 44.4 & 55.6 & 0 & 16.7 & 83.3 \\
\hline P3 - Task completion/ perseverance & 16.7 & 27.8 & 55.6 & 0 & 27.8 & 72.2 & 0 & 16.7 & 83.3 \\
\hline PT 1 - Adaptive Responsiveness & 44.4 & 55.6 & 0 & 55.6 & 27.8 & 16.7 & 16.7 & 27.8 & 55.6 \\
\hline PT 2 - Audience Awareness & 83.3 & 16.7 & 0 & 38.9 & 44.4 & 16.7 & 11.1 & 38.9 & 50.0 \\
\hline SR 1 - Negotiation & 0 & 0 & 0 & 0 & 0 & 0 & 0 & 44.4 & 55.6 \\
\hline SR 2 - Self-evaluation & 16.7 & 0 & 0 & 0 & 0 & 0 & 0 & 16.7 & 0 \\
\hline SR 3 - Transactive memory & 0 & 0 & 0 & 0 & 0 & 0 & 0 & 0 & 0 \\
\hline SR 4 - Responsibility initiative & 100 & 0 & 0 & 83.3 & 16.7 & 0 & 44.4 & 33.3 & 22.2 \\
\hline
\end{tabular}


Table 2 Percentage of students performing collaboration skill during engineering design activity in meeting 3 and meeting 4.

\begin{tabular}{|c|c|c|c|c|c|c|c|c|c|}
\hline \multirow{3}{*}{ Elements of Collaboration Skills } & \multicolumn{9}{|c|}{ Engineering Design Process } \\
\hline & \multicolumn{3}{|c|}{ Construct prototype } & \multicolumn{3}{|c|}{ Test the prototype } & \multicolumn{3}{|c|}{ Redesign } \\
\hline & Low & Mid & High & Low & Mid & High & Low & Mid & High \\
\hline P1-Action & 0 & 16.7 & 83.3 & 0 & 11.1 & 88.9 & 0 & 11.1 & 88.9 \\
\hline $\mathrm{P} 2$ - Interaction & 0 & 0 & 100 & 0 & 0 & 100 & 0 & 0 & 100 \\
\hline P3 - Task completion/ perseverance & 0 & 16.7 & 83.3 & 0 & 50 & 50 & 0 & 50 & 50 \\
\hline PT 1 - Adaptive Responsiveness & 0 & 72.2 & 27.8 & 22.2 & 66.7 & 11.1 & 22.2 & 61.1 & 16.7 \\
\hline PT 2 - Audience Awareness & 16.7 & 66.7 & 16.7 & 16.7 & 72.2 & 11.1 & 27.8 & 61.1 & 11.1 \\
\hline SR 1 - Negotiation & 11.1 & 44.4 & 44.4 & 16.7 & 22.2 & 61.1 & 55.6 & 22.2 & 22.2 \\
\hline SR 2 - Self-evaluation & 0 & 0 & 0 & 11.1 & 16.7 & 0 & 0 & 0 & 0 \\
\hline SR 3 - Transactive memory & 0 & 16.7 & 0 & 11.1 & 0 & 0 & 0 & 0 & 0 \\
\hline SR 4 - Responsibility initiative & 27.8 & 44.4 & 27.8 & 27.8 & 44.4 & 27.8 & 16.7 & 27.8 & 44.4 \\
\hline
\end{tabular}

$\mathrm{P}=$ Participation; $\mathrm{PT}=$ perspective taking; $\mathrm{SR}=$ Social Regulations

Descriptive analysis of each sub skills and its elements indicates that during identifying problem students perform high level of participation (55.6\%). Differently, on perspective taking, middle level of adaptive responsiveness (55.6\%) and low level of audience awareness (83.3\%) are dominating. In terms of social regulation, no negotiation and transactive memory found. Only a few students perform low self-evaluation $(16.7 \%)$ and all students shown low responsibility initiative (100\%).

During developing possible solution, higher level of perseverance is evident (72.2\%). 16.7\% students perform high level of perspective taking and middle level of responsibility initiative which are previously performed in lower level. There was no indication of negotiation, self-evaluation and transactive memory during this process.

During designing prototype, the number of students performing high level of interaction (83.3\%), perseverance (83.3\%), adaptive responsiveness (55.6\%), audience awareness (50\%), and responsibility initiatives $(22.2 \%)$ are increasing. Surprisingly, 55.6\% students perform high level of negotiation and the rest of the students are in middle level. Middle level of self-evaluation appeared as much as $16.7 \%$.

The number of students performing high level of action (83.3\%) and interaction (100\%) increased during constructing the prototype. Most of the students performed middle level of perspective taking (adaptive responsiveness $72.2 \%$; audience awareness $66.7 \%$ ). Negotiation is still dominated by middle (44.4\%) and high (44.4\%) level. A few students shown middle level of transactive memory (16.7\%) and the number of students performing low level of responsibility initiative is decreasing compared to previous lesson as it increase in middle (44.4\%) and high (27.8\%) level.

During testing the prototype and redesign, only 50\% students shown high level of perseverance, the rest is in middle level. Both elements of perspective taking is somewhat dominated by middle level performer. $61.1 \%$ 
students show high level of negotiation during testing and 55.6\% students show low level of negotiation during redesign. There were evident of self-evaluation (low 11.1\%; middle 16.7\%) and transactive memory (11.1\%) during testing, but none during redesign. $44.4 \%$ students shown high level of responsibility initiatives while the rest are in middle $(27.8 \%)$ and low $(16.7 \%)$ level.

Students' average score on each element of collaboration skills indicate that the highest performance of action occurred during testing and redesign (0.96). All of students perform highest level of interaction during constructing, testing and redesigning. Perseverance best performed during designing (0.94) and constructing (0.94). The highest average score for adaptive responsiveness $(0.80)$, audience awareness $(0.80)$ and negotiation (0.85) found in designing. Responsibility initiatives best performed during redesign (0.69). The elements of collaboration skills with least score were self-evaluation (highest: 0.15 during testing) and transactive memory (highest: 0.11 during constructing).

\section{Discussion}

The results indicate that within engineering design activity, high degree of students' participations is evident throughout the lesson. This implies that students were actively engaged in the lesson by doing activities within environment, interacting with others, responding to the contributions of others as well as shows perseverance in undertaking and completing the task.

Perspective taking skills were also observable along the lesson, where the highest degree of both adaptive responsiveness and audience awareness were found in designing prototype. It is because during this engineering design process, students have opportunity to express their ideas to other, accept others' ideas and some students were even able to adapt and incorporate those ideas to suggest the best design for their solution. From the recording it is also found that students often asked for further clarification when they are trying to understand other's ideas. As Hesse et al (2015) describe, "responding skills become apparent when problem solver manage to integrate contributions of collaborators into their own thoughts and actions".

From the observation it is also found that when a student asked for clarification of ideas to other, it will enable other student to perform audience awareness skills by making sure that their utterance or action can be understood by their collaborating partner. Yet, when a student ignored ideas of other, there is no opportunity for the other students to express ideas in details, making them lies in low level of audience awareness. Thus, this finding suggests that somehow individual collaboration skills are dependent upon skills of collaborating partner.

In terms of social regulation skills, responsibility initiative elements were observable in every meeting. This finding suggests that during engineering design activity students were able to take responsibility for working on a shared problem representation, developing plan toward solution and regularly monitor group progress.

Differently, negotiations were absent during identifying problem and developing solution process. This is happened because during these two engineering design processes, teacher did not provide opportunity for group discussion. Instead, teacher led whole class discussion to help students identify the problem and its possible solution. Sample of problem statement and solution were written on the white board which may cause students to use it as their answer without further negotiation. Teacher led whole class discussion instead of group discussion because the students were still have difficulties in identifying the problem by themselves. Thus teacher guidance is needed. The same thing happened during brainstorming possible solutions.

On the other hand, during the rest of the engineering design processes, students performed high degree of negotiation. It may be explained by the fact that during designing, constructing, testing and redesigning, students often come up with diverse opinions and strategies that rise conflict among group members. As conflict arises 
students are pushed to negotiate the steps and measures that accommodate the differences between individual approaches (Hesse et al, 2015).

Self-evaluation and transactive memory were not identified as much as other skills. Students may recognize his or her own and others' strengths and weaknesses through communication (Wegner, 1986) during collaborative work. However without making utterance acknowledging those strengths and weaknesses, these two skills were not observable. Thus it can be inferred that this engineering activities somehow did not accommodate all students to express group diversity in terms of one's and others' knowledge, strengths and weaknesses.

\section{Conclusion and Recommendation}

Based on the analysis of the findings we confidently suggest that varied level of collaboration skills are evident throughout science lesson incorporating engineering design activity. This is due to the nature of engineering activity which provides students with debatable content where varied perspectives exist. Moreover, individual collaboration skills are dependent upon skills of collaborating partner as there is interdependence among group members.

In addition, for further relevant studies we suggests to exposed students to problems which is contextual and relatable to their life to make them easier in identifying the main problems as it is a crucial part to begin the activity. Thus, students can engaged in group discussion instead of class discussion led by teacher that may enable them to perform negotiation. Nonetheless, we do hope that this study prompts future work to shed light on how engineering design activities in science lesson may foster collaboration skills as an essential 21st century skills when compared to other activities.

\section{References}

Assessment and Teaching of 21st Century Skills Project. 21st Century Skills. Date of access: 28/11/2017. http://www.atc21s.org/

Bagiati, A., \& Evangelou, D. (2016). Practicing engineering while building with blocks: identifying engineering thinking. European Early Childhood Education Research Journal, 24 (1), 67-85.

Barrett, B. S., Moran, A. L., \& Woods, J. E. (2014). Meteorology meets engineering: an interdisciplinary STEM module for middle and early secondary school students. International Journal of STEM Education, 1 (1), 1-6.

Griffin, P., McGraw, B., \& Care, E. (2015). Assessment and Teaching of 21st Century Skills Methods and Approach (Dordrecht: Springer).

Guzey, S. S., Moore, T. J., Harwell, M., \& Moreno, M. (2016). STEM Integration in Middle School Life Science: Student Learning and Attitudes. Journal of Science Education and Technology, 25 (4), 550-560.

Han, S., Capraro, R., \& Capraro, M. (2014). How science, technology, engineering, and mathematics (stem) project-based learning (PBL) affects high, middle, and low achievers differently: the impact of student factors on achievement. International Journal of Science and Mathematics Education. 13(5).

Hernandez, P. R., Bodin, R., Elliott, J. W., Ibrahim, B., Rambo-Hernandez, K. E., Chenen, T. W., \& de Miranda, M. A. (2014). Connecting the STEM dots: measuring the effect of an integrated engineering design intervention. International Journal of Technology and Design Education, 24(1), 107-120. 
Hesse F., Care E., Buder J., Sassenberg K., Griffin P. (2015) A Framework for Teachable Collaborative Problem Solving Skills. In: Griffin P., Care E. (eds) Assessment and Teaching of 21st Century Skills. Educational Assessment in an Information Age. Springer, Dordrecht

Householder, D. L., \& Hailey, C. E. (2012). Incorporating Engineering Design Challenges into STEM Courses. Publication. Paper 166. Available at: http://digitalcommons.usu.edu/ncete_publications/166.

Kemendikbud. (2017). Model Silabus Mata Pelajaran Sekolah Menengah Pertama/Madrasah Tsanawiyah (SMP/MTs) Mata Pelajaran Ilmu Pengetahuan Alam. Jakarta: Kementrian Pendidikan dan Kebudayaan.

Lai, E. R., DiCerbo, K. E., \& Foltz, P. (2017). Skills for Today: What We Know about Teaching and Assessing Collaboration. (London: Pearson).

Lee, D., Huh, Y., \& Reigeluth, C. M. (2015). Collaboration, intragroup conflict, and social skills in projectbased learning. Instructional Science, 43(5), 561-590.

Marulcu, I., \& Barnett, M. (2016). Impact of an engineering design-based curriculum compared to an inquirybased curriculum on fifth graders' content learning of simple machines. Research in Science \& Technological Education, 34 (1), 85-104.

Moreno, N. P., Tharp, B. Z., Vogt, G., Newell, A. D., \& Burnett, C. A. (2016). Preparing Students for Middle School Through After-School STEM Activities. Journal of Science Education and Technology, 25(6), 889-897.

OECD. (2017). PISA 2015 Assessment and Analytical Framework Science, Reading, Mathematic, Financial Literacy and Collaborative Problem Solving. OECD Publishing.

Partnershio for 21st Century Learning. P21 Framework Definitions. Date of access: 25/1/2018. http://www.p21.org/storage/documents/P21_Framework_Definitions.pdf

Riebe, L., Girardi, A., \& Whitsed, C. (2016). A systematic literature review of teamwork pedagogy in higher education. Small Group Research, 47(6), 619-664.

Roschelle, J. \& Teasley, S. D. (1995). The construction of shared knowledge in collaborative problem solving. In C. E. O’Malley (Ed.), Computer-supported collaborative learning (pp. 69-197). Berlin: Springer-Verlag.

Rush, D. L., Integrated STEM Education through Project-Based Learning. Date of access: 15/12/2017. https://www.rondout.k12.ny.us/common/pages/DisplayFile.aspx?itemId=16466975

Schnittka, C. G., Evans, M. A., Won, S. G. L., \& Drape, T. A. (2016). After-School Spaces: Looking for Learning in All the Right Places. Research in Science Education, 46 (3), 389-412.

Stevens, M. J., \& Campion, M. A. (1994). The knowledge, skill, and ability requirements for teamwork: Implications for human resource management. Journal of Management, 20(2), 503-530.

Wendell, B. K., \& Rogers, C. (2013). Engineering Design-Based Science, Science Content Performance, and Science Attitudes in Elementary School. Journal of Engineering Education, 102 (4), 513-540.

Yanyan, L., Zhinan, H., Menglu, J., \& Ting-Wen, C. (2016). The Effect on Pupil's Science Performance and Problem-Solving Ability through Lego: An Engineering Design-based Modeling Approach. Journal of Educational Technology \& Society, 19 (3), 143-156. 